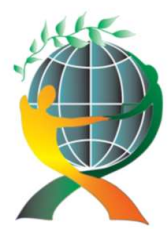

\author{
(online) $=$ ISSN $2285-3642$ \\ ISSN-L = $2285-3642$ \\ Journal of Economic Development, Environment and People \\ Volume 8, Issue 3, 2019
}

URL: http://jedep.spiruharet.ro

e-mail: office jedep@spiruharet.ro

\title{
How Globalization Influences the Developing Countries' Human Resources Strategic Policy
}

\author{
Rahil ASADI ${ }^{1}$, Gabriel Octavian MARIN² \\ The Bucharest University of Economic Studies, Romania ${ }^{1 *}$, \\ RoAssurance; Bucharest, Romania²
}

\begin{abstract}
Development of human resources is one of the key issues of today's economics and management scholars. Starting from the basic concepts of human resources - definition, trends of development, related indicators the present research evolves under three components: education, life expectancy and gross domestic product per capita. Figures that sustains our demarche flow according to the ranking data in terms of globalization index and The United Nations Human Development Index (HDI), calculated with the STATGRAF statistical software. We used the Spearman correlation coefficient and correlated the intensity between the two variables ( $R=76 \%)$, to show the close relationship between the Globalization Index and Human Resource Development. Taking such conclusions into consideration, could make more successful the advances in the field of human resources.
\end{abstract}

Keywords: Human resources, Globalization, Human resource development JEL Codes: O15, F66, 02

How to cite: ASADI, R., \& MARIN, G. (2019). How Globalization Influences the Developing Countries' Human Resources Strategic Policy. Journal of Economic Development, Environment and People, 8(3), 32-46. doi:http://dx.doi.org/10.26458/jedep.v8i3.625

\section{Introduction}

The development in terms of definition and action has always been one of the most controversial economic issues. Reducing the poverty and inequality that plagued society during the last 70 years led to an emergence of economists specialised in development, able to providing an environment for the advent of different views, patterns, and ideas to get rid of these problems. Thus, the first group of economists defining the development process focused on economic growth. The welfare economic approach about the development topics led to the use of goods and services as the basis elements to determine economic prosperity. Therefore, the amount of national income was considered as a criterion in order to measure the welfare and development (or the consumption amount of goods and services), of the country. In this approach, the issues of poverty and the distribution of income are ignored, because it is an assumption that everyone can benefit from the GDP increase. Opposite to this perception appeared the approach of development peaked in the mid-1970s. Many countries accomplished their economic growth goals, but it did not change the living conditions at society level. Nevertheless, some of the new development functions and tasks such as "growth with equity" and "redistribution of growth" were considered by development

\footnotetext{
${ }^{1}$ E-mail address: rahil.asadi65@yahoo.com; ro.assurance@yahoo.com.
} 


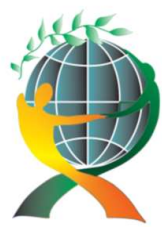

\author{
(online) $=$ ISSN $2285-3642$ \\ ISSN-L = 2285 - 3642 \\ Journal of Economic Development, Environment and People \\ Volume 8, Issue 3, 2019 \\ URL: http://jedep.spiruharet.ro \\ e-mail: office jedep@spiruharet.ro
}

economists, giving a special place to social and human concepts in the definitions of national development. 1999 Human Development Report mentions when refers to the relationship between economic growth and human development: "Despite rapid economic growth in fifteen countries over the past three decades, about 1.6 billion people have become poorer and their lives, situation has been worse than fifteen years ago". In fact, if preventive policies do not apply for the proper distribution of growth, the human resources will not grow and develop in the right way and proper direction. Therefore, the report outlines that no automatic link and connections between economic growth and human development can identify without the presence of policy-making and decision-making as the two mutual contributors to affect economic growth and help to improve human development.

Overtime, attention to human place and to his true status became the main component of development process phenomenological concepts. Development is a comprehensive move that involves major changes in social, economic, and national institutions to achieve widespread human welfare. Today, the main component of human welfare is about the development of individual choices. In societies which, people have the power to choose more and more in terms of economic, social, political and has freedom of speech and express personal beliefs, are more successful and more developed at providing human wellbeing. So the concept of the development process evolves from economic growth to human development and the development goals have improved much bigger than the past. According to this, we retain for analyse here several elements emphasised below: definition of human resource development and its related indicators; how a historical perspective of concept springs the development process; what is the relationship between the human resource and the globalization process; how important and necessary are the review and assessment processes for the status of the human resources' needs; does the relationship between the globalization and national development strategies deserve a careful examine and investigation?

\title{
2. Conceptualization of Globalization
}

In the 20th century, the transformation and development processes entered in a new phase influencing, during the mid-1980s, almost all sectors of activity. New concepts started to be studied: industrial society and postmodernism. The 1990s brought the concept of globalization becoming the today life dominant.

Globalization signifies as a process of intensification of political, technology, economic, social and cultural interconnectedness among the various actors in the global system at countries. It means the absolute freedom of business, and eliminates of all barriers to the easy flow of capital and its influence in all areas of information flow, financial affairs, services and, finally, the exchange of cultures in a coherent way and all have occurred at the global scale. (Vujakovic, 2010)

Globalization can eliminate borders and identities, care and attention to the people, goods, information, habits, norms, and institutions and allowing borders to be moved. The agricultural revolution, and then the revolution in the industrial and post-industrial age, is among the main reasons of the booster for the phenomenon of globalization. (Axel et al, 2019). Globalization is the multi-dimensional phenomenon, there is no doubt that the main aspect of globalization and what is agreed upon and criticized against this phenomenon, it's there economic effected and result. Hence, in this research its necessary, first to get, know the economic source of this globalization process. 


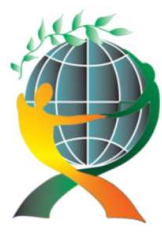

\author{
(online) $=$ ISSN $2285-3642$ \\ ISSN-L = $2285-3642$ \\ Journal of Economic Development, Environment and People \\ Volume 8, Issue 3, 2019 \\ URL: http://jedep.spiruharet.ro \\ e-mail: office jedep@spiruharet.ro
}

The globalization process is, in fact, a part of a historical process of social evolution and, in the opinion of some economist, it is due to the nature and essence of capital growth, the effort to survive and acquire new and profitable markets and the need to export capital from saturated markets to potential markets. While these funds and capital transfer has many positive and negative consequences for the underdeveloped and developing countries. In general, we can say that the economic basis of the globalization phenomenon is the economic neoliberalism.

Globalization obviously has also a political dimension. In the political arena it leads to the growth of transnational operations, the growth of neighbourhoods and global cities that create global functions and activities, the decline of the effectiveness of political instruments of government, the reduction of government authority and in general, the emergence of a new political space.

The social and cultural dimension is the main aspect of conflict and opposition at the process of globalization because the migration and brain drainage will increase, which leads to demographic deformation of many countries of the world. There is no consensus, among those who have addressed the issue of globalization from the social dimension and culture, some people have considered it a plausible phenomenon and all have to submit that sooner or later and they should give up and accept it. Others have said that communities are free to accept or reject it and all must have the authority to decide on it. Those who consider globalization as the unselective and indiscriminate phenomenon, they argue that globalization is occurring in the present time due to economic, political, scientific developments and the communications developments, and countries must inevitably adapt themselves to this process. (Lundby \& Jolton, 2010). Based on this notion, it must be accepted that particular culture will impose its domination on ethics, art, economics, politics, as well as in the individual and social behaviours of human and the world will eventually become at the same cultural heritage. But those who do not have this perception of globalization, believing that globalization phenomenon do not mean the domination of a particular culture on all countries in the world. Because all humans are members of the international community, they must think about the issues that the international community is facing and work together to overcome the bottlenecks that humanity faces. While accepting cultural pluralism as a reality, they introduced the idea of dialogue among civilizations, cultural understanding, achievement values shared, mutual respect, international participation, and patience as the best solution to the effects of globalization in the cultural and social aspects. In this context, some have said that the formation of global culture does not lead to the disappearance of national and regional cultures of cities. Because native cultures have a powerful value system and global culture cannot digest these cultures. If a culture is declining, it is due to the internal weakness of that culture, not to the emergence of a global culture and the globalization phenomenon (Huntington \& Harrison, 2000).

\title{
3. Phenomenological Aspects of Human Resource Development
}

Today's manpower and human resource are seen as a valuable asset that has the power of reproduction. In fact, the quality of human resource and their performance is the main issue in all developed countries and they try to make a system for equipping and upgrading human resources and maintaining it in a comprehensive and dynamic manner. In 1990, the first human resource development UNDP Report defined the human resource as "the process of expanding the range of human choices". Seven years later, the definition was reformulated stating that "human resource development is a process that 


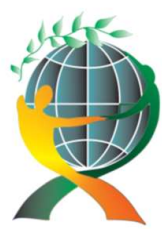

\author{
(online) $=$ ISSN $2285-3642$ \\ ISSN-L = $2285-3642$ \\ Journal of Economic Development, Environment and People \\ Volume 8, Issue 3, 2019 \\ URL: http://jedep.spiruharet.ro \\ e-mail: office jedep@spiruharet.ro
}

adds to human well-being, making possible to have better choices, expanding the richness of human life rather than that of the economy in which human beings live. Thus, the new definition of human resource development is focused on people, choices and opportunities.

Walton defines human resources development process as "a set of organizational activities that take place over time and designed to make behavioural change in the staff". The main strategic resource of any organization or any society is their human resources (Kornai et al, 2009). In the long run, societies will succeed, if they are able to develop and cultivating their human resources properly and in principle, along with enhancing their knowledge and developing the required technical skills. According to the new concept of human resource development, the organizational human resource should be equipped with qualities that have no conflict with the organization's aim and strategies. The human resource has to use all abilities, energy, expertise and thoughts, with compassion, commitment and scientific insight in the same direction with organizational missions. Human resource has to constantly create new intellectual and qualitative values for the organization. In general, the human resource development process has the following components: create scientific knowledge and promoting employee knowledge, create scientific and balance behaviour at an employee, promote employee capabilities and create added-value as quality for employees, develop work skills performance, improve and update employees' information and the ability to solve problems scientifically, develop people personality and ability for rational decision making combine and build new collections. To fulfil and achieve all those components requires a change in the understanding, attitude and behaviour of human resources and all these changes are possible by training and improving human resources.

Education and training are considered the best in creating and increasing knowledge, skills and improving the attitude and performance of human resources. The main focus of globalization is the human resource development process. In this regard, the university training and educations are especially important for achieving human resource development goals. Also, this will improve the index of human resource development and the country will move towards the knowledge-based development and its indicators too. Efficient manpower in a country is one of the most valuable assets of that country. Basically, "knowledge capital" is more important than "production capital". Nowadays the developing countries use human capital more than physical capital, according to statistics, human resource has the primary role of wealth creation in developed countries with $67 \%$, while the share of natural and physical resources is only $33 \%$. It is the human capital that can be used as the backbone of the great social movement of the $21^{\text {st }}$ century. (HDI, 2019).

Human development is a concept that seeks to bring human to development, in other words, human development is ultimately a process that focuses on the development of people's choices. In the first Universal Report on Human Development 1990, "The process of developing human choices" is presented as a definition of development. In the human development approach, consumption of goods and services alone cannot provide prosperity, but the expansion of the needful facilities such as education and health for the use of capabilities and abilities as well as the development of capabilities are considered as the main components of development. Therefore, improving human capabilities such as political and civil liberties, education, health and economic power should be considered as the main focus of underdeveloped societies. People remain the main wealth of communities, and the aim of the development process is to provide better living conditions with more security. Attention to the challenges that humanity face in the 


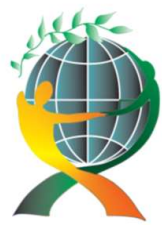

\author{
(online) $=$ ISSN $2285-3642$ \\ ISSN-L = $2285-3642$ \\ Journal of Economic Development, Environment and People \\ Volume 8, Issue 3, 2019 \\ URL: $\underline{\text { http://jedep.spiruharet.ro }}$ \\ e-mail: office jedep@spiruharet.ro
}

society, it requires that people be at the centre of the development process. Therefore, economic growth is not seen as the main goal but as an instrument for increasing life's opportunities. Elimination of all problems such as poverty, hunger, disease, war, inequality, illiteracy, and so on, all are the reason to find the ways to expand human capabilities and choices, and that is the main reason in the benchmark of human development process; it has been emphasized on three dimensions of education, income and health.

\title{
4. Human Development Index and its Components
}

The Human Development Index, as the main focus of human development reports, represents the latest international effort to find a developmental measurement unit for all countries. It is developed based on three criteria: education, life expectancy and gross domestic product per capita. The use of these criteria is due to their important, undeniable role and impact in enhancing human capabilities. (Baklouti \& Boujelbene, 2018) The Human Development Index aims to increase the power of choosing and expanding human capabilities, and evaluate the amount of success in the process of human development. Human development index will represent the trend of the human development process in the world and its useful for comparison the status of countries in relation to each other. Although, the Human Development Index has not released its criticism, such as criticizing the number of selected criteria and the ways of choosing weights in calculating the index, but it still retains its popularity. Since this index can give the view of the human development situation and its global position then understanding the components of this index and its analysis, is a necessary and important subject (Analoui, F. 2000).

The latest international effort to measure the degree of development and international comparison of countries, it is led to the creation of the Human Development Index (HDI) by the United Nations Development Program in 1990. Since its first release in 1990, it has been published annually in the form of reports by the United Nations and is being used by various countries and international organizations. The Human Development Index is a combination of four different criteria that have three components: life expectancy, education and GDP per capita. The Human Development Index is a simple average of the three components above. (Vujakovic, 2010) Life expectancy, education, and real income are all factors that increase the power of human's choosing. Lifespan as an index to measure the life expectancy, it is also can showing better nutrition and having health facilities, and provides more opportunities for life and choice for humans. Education also can learn people how to think and the power of decision making and also the power to take advantage of using the opportunities. Today, except the role of education in the human development process, it is also emphasized as its impact on economic growth, and ultimately the impact of real income growth on the expansion of individuals' free choice and using the material resources. Therefore, UNDP uses three indicators to measure human development index. The value of each indicator is calculated according to the following formula:

\begin{tabular}{|r|l|}
\hline DIMENSIONS & \multicolumn{1}{|c|}{ INDICATOR } \\
\hline Health & Life expectancy \\
\hline Education & Expect years of study \\
\cline { 2 - 2 } & Mean years of study \\
\hline Standard of living & Gross domestic income per capita \\
\hline
\end{tabular}




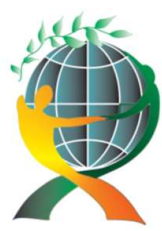

\author{
(online) $=$ ISSN $2285-3642$ \\ ISSN-L = $2285-3642$ \\ Journal of Economic Development, Environment and People \\ Volume 8, Issue 3, 2019 \\ URL: http://jedep.spiruharet.ro \\ e-mail: office jedep@spiruharet.ro
}

\author{
Index value $=($ Index value for the target country- Min value of index $)$ \\ Max value of index- Min value of index
}

The minimum and maximum of each index are calculated based on the UN's assumptions.

Life expectancy. The World Health Organization defines health as "good and favourable physical, mental, and social situation of a person". The full health situation is the physical, psychological and social health and it's not only being a lack of illness or disability. From the above definition, it is concluded that human and his health are provided or threatened from the three aspects of physical, mental and social relationships. Each society's goal is to ensure and guarantee the health of members of the community and the mental health is part of overall human health. In terms of mental health, it is a particular aspect of human being, such as intelligence, mind, mood, and thought. What is threatens health conditions; it is not merely a factor but a combination of multiple factors that lead to non-healthy behaviour. Therefore, it is very necessary to examine society's realities and needs, predisposing factors, and other social factors for providing educational materials and their evaluation (Hansen \& Strulik, 2017). The minimum and maximum life expectancy limits are 25 and 85 years. The value of this indicator for Iran based on the latest Human Development Report (2017), calculated for 2015, is 0.746 since calculating this indicator is the only measure of life expectancy, so its value is equal to the value of the life expectancy index (HDI, 2019).

Education. Education has always been known as the reliable main tools for improving the quality of performance and solving management problems and the lack of education is one of the basic and acute issues of each organization. Therefore, to equip the human resources and to improve and utilize them as much as possible, it's necessary to use education and education is undoubtedly one of the most important and effective measures for improvement of the organization's affairs. It should be noted that education is a fundamental task in organizations and is a continuous and on-going process that is not a temporary process. Employees at each level of the organization, whether their work is simple or complex, they are manager or subordinate, all need education and learning, and acquire new knowledge and skills. The human resource needs to learn the new methods, techniques and information to do their job better and, in addition, whenever a job is changed, new skills and knowledge are needed to educate to continue successfully and complete the tasks for the relevant occupation. For the education indicator, there are two criteria: adult literacy rate and gross enrolment rate as a combination of enrolment rates for elementary, secondary and higher education. The adults' literacy rate is including those people over the age of 15 who are able to read and write their brief statements. The ratio of gross enrolment for elementary, secondary and high school education is equal to the average of the ratios of student enrolment in each educational field as a percentage of the population in each age group. (Sodagary, 2019). The United Nations believes that literacy is the first step in learning and educations base plan. Therefore, in calculating the education index, the adult literacy rate has been given a higher rate, in the calculation of the education index, the adult literacy rate is considered with the combined rate of gross enrolment with a two-thirds coefficient (Payne, 2019) given that the minimum and maximum values of both training criteria are zero and 100 . The value of Iran's education index for 2011 was calculated at 0.787 .

Gross Domestic Product per capita. The calculation of gross domestic product per capita is more complicated than other indicators. Since this index is calculated using a logarithmic formula, therefore the 


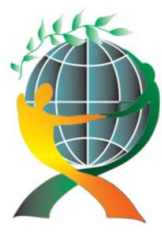

\author{
(online) $=$ ISSN $2285-3642$ \\ ISSN-L = $2285-3642$ \\ Journal of Economic Development, Environment and People \\ Volume 8, Issue 3, 2019 \\ URL: http://jedep.spiruharet.ro \\ e-mail: office jedep@spiruharet.ro
}

importance of increasing GDP (the index of per capita) in its higher values is diminished. For example, an increase of \$ 100 in GDP per capita in Iran will increase Iran's human development index more than the Canadian Human Development Index, for the same amount of GDP rate growth. The method of calculating GDP (per capita) is as follows:

GDP $=$ gross domestic product per capita, GDPX = Gross domestic product per capita for the country $(x)$

GDP $\min =$ Minimum gross domestic product per capita of $\$ 100$ (PPP) is 1 ;

GDP $\max =$ Maximum gross domestic product per capita is $\$ 40,000$ (PPP);

Iran's GDP per capita for 2011, according to the latest human development report, was $\$ 7,681, \$ 1,176$ higher than in the year 2010 which it was $\$ 6,505$ and the interesting is to look back a few years ago and compare with the year 2001 when the GDP was $\$ 5,120$.

Calculation of the human development index. In order to calculate the human development index, three indicators of life expectancy, education and gross domestic product per capita are taken as average (Todaro \& Smith, 2006). The rank of HDI for country Iran for the year 2011 is calculated based on data for the year 2012 was 74. Between 187 countries and during 1980 until 2012, the HDI rate increased to 0.742 is the increase of average around 1.6 percentages.

\title{
5. Measures Sustaining the Human Capital Development by Productivity Increase
}

The subject of human resources development and its relations with productivity is one of the major issues in HRM. (Watts, 2011) Human resource development focuses on education and development, and is based on these assumptions in bellow:

- Persons (human resources) are the most valuable source of the organization.

- Development processes is a long-term activity, and in this regard, the role of education is very important.

- The task of the managers is to develop human resource because managers are responsible for their work its environment.

- Managers are the centrepiece of the most meaningful and long-lasting of a business and their coworkers.

- Productivity refers to the efficient use of all resources to get the maximum value added of them. Therefore, the development of human resources means storage of the skills, organization, and learning experiences in order to realize the goals of the business. Hence, through the development of skills, knowledge, competency, learning power and interest of human resource at all levels, it makes the continuous organizational growth and organizational growth leads the growth and development of people.

Therefore, from a systematic and strategic perspective point view, the productivity through human resource development means that managers must be aware of all angles, aspects and environment of the organization and, accordingly, set up functional and effective HR development plans for their organization, with regard to their impact on productivity. In addition to developing human resources, managers must make great efforts to create the right mental environment. Human resource as the most important factor of productivity, once they have an optimal level of motivation at workplace, they will achieve productivity more sufficient, competent and faster (Pinkovskiy,2017). In order to strengthen and increase the human 


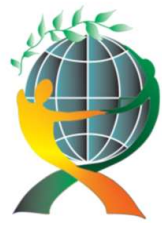

\author{
(online) $=$ ISSN $2285-3642$ \\ ISSN-L = 2285 - 3642 \\ Journal of Economic Development, Environment and People \\ Volume 8, Issue 3, 2019
}

URL: http://jedep.spiruharet.ro

e-mail: office jedep@spiruharet.ro

resource's motivation, a manager should attention to the work environment, their individual needs and their economic problems. A suitable mental or a conductive environment to accomplish the desired work, and also appropriate to their level of skill, interest, and training, makes the satisfaction of people from work. As a result, below factors affecting productivity are provided.

The most important of these factors are: employee perceptions of their work and organization; the nature of the work; specialist knowledge and information at work; work culture; mental and physical balance of the staff; individuals' motivation for optimally perform their work; employee morale and job satisfaction; degree of cooperation of individuals in the organization; discipline in work and time management; employees' participation in decision making; effective and efficient management; availability of training facilities; innovation, creativity and environment provide for creativity development; experience and proper records for tasks. All of the above factors help to create an appropriate mental environment and provide the necessary environment base for increasing productivity.

The availability of communication facilities is one of the most important indicators of the human development process and part of the Global ranking of communication facilities development 2008-2018 and human development report compares the country's telecommunications indices (Global Internet usage, 2019).

Table 1: Global ranking of communication facilities development 2008-2018 (Source: ITU World, 2019

\begin{tabular}{|l|l|l|l|l|l|l|l|l|l|l|l|}
\hline ICT developments & $\mathbf{2 0 0 8}$ & $\mathbf{2 0 0 9}$ & $\mathbf{2 0 1 0}$ & $\mathbf{2 0 1 1}$ & $\mathbf{2 0 1 2}$ & $\mathbf{2 0 1 3}$ & $\mathbf{2 0 1 4}$ & $\mathbf{2 0 1 5}$ & $\mathbf{2 0 1 6}$ & $\mathbf{2 0 1 7}$ & $\mathbf{2 0 1 8}$ \\
\hline $\begin{array}{l}\text { Mobile-cellular } \\
\text { telephone } \\
\text { subscriptions }\end{array}$ & 59.7 & 68.0 & 76.6 & 84.2 & 88.5 & 93.1 & 96.7 & 98.2 & 100.7 & 103.6 & 107.0 \\
\hline $\begin{array}{l}\text { Individuals } \\
\text { using Internet }\end{array}$ & 23.1 & 25.5 & 28.9 & 31.3 & 34.3 & 36.9 & 39.9 & 43.0 & 45.8 & 48.6 & 51.2 \\
\hline $\begin{array}{l}\text { Land-phone } \\
\text { subscriptions }\end{array}$ & 18.5 & 18.4 & 17.8 & 17.2 & 16.7 & 16.0 & 15.1 & 14.2 & 13.5 & 13.0 & 12.4 \\
\hline $\begin{array}{l}\text { Active mobile- } \\
\text { broadband } \\
\text { subscriptions }\end{array}$ & 6.3 & 9.0 & 11.5 & 16.9 & 21.9 & 27.4 & 36.8 & 45.1 & 52.2 & 62.0 & 69.3 \\
\hline $\begin{array}{l}\text { Land-broadband } \\
\text { subscriptions }\end{array}$ & 6.1 & 6.9 & 7.6 & 8.6 & 9.2 & 9.7 & 10.1 & 11.4 & 12.3 & 13.3 & 14.1 \\
\hline
\end{tabular}




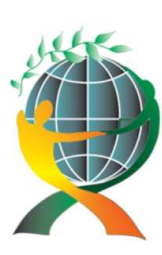

\author{
(online) $=$ ISSN $2285-3642$ \\ ISSN-L = $2285-3642$ \\ Journal of Economic Development, Environment and People \\ Volume 8, Issue 3, 2019
}

URL: http://jedep.spiruharet.ro

e-mail: office jedep@spiruharet.ro

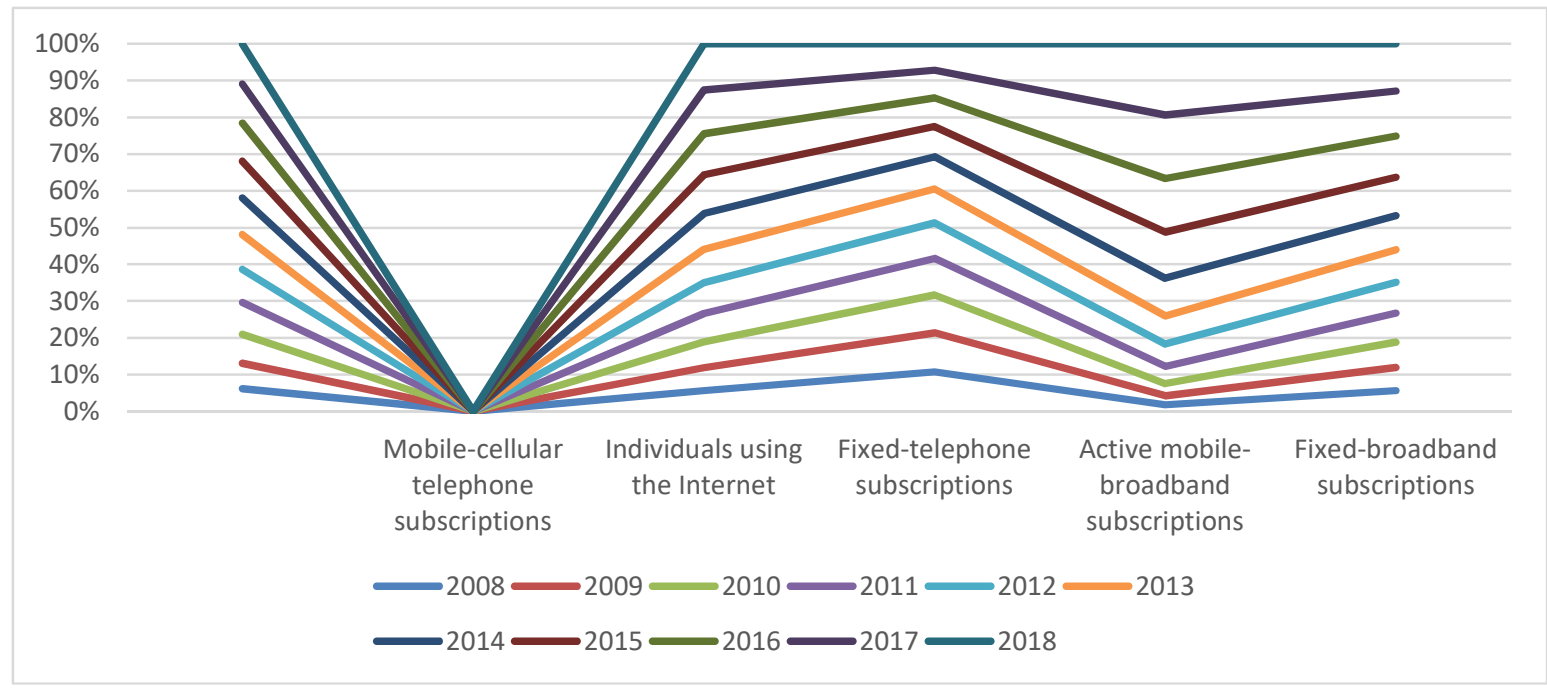

Fig.1: Global ranking of communication facilities development Source: Global Internet usage, 2019

\title{
6. About the Index of Human Development
}

The most important indicator of the UN Human Development Report is about the Human Development Index (HDI), which combines indicators of products per capita, Indices of life expectancy and indicators of educational and health status, Owens, E. (1987). So, we can say in general, the human development index focuses on these 3 three factors, for this reason, the HDI Index is a very good tool for assessing the status of development and prosperity of countries in comparing to each other. (Watts, 2011)

According to the Human Development Report ("Human Development Reports | United Nations Development Programme," 2019) as in the past few years, Norway has the first ranked. Norway, which ranked first in the UN, HDI Index, between 2002 and 2005, it spends about 7.6\% of gross domestic product GDP for the education sector. While at 2000, for about $7 \%$ of its gross domestic product spend in education. Between the selected countries in Table 2, the Malaysian education sector has grown most in the period of 2002 to 2005 . This country had only 5.1 percents of its GDP in 2000, but in the period from 2002 to 2005 , the share of education has increased to $8.1 \%$ of its production sector.

Iran, with a human development rate of 99, has allocated 4.9 per cent of its GDP to the education sector in 2002-2005, While in 2002, it accounted for 4.1 percents of the gross domestic product. By contrast, the Pakistani country with a human development rank of 135 has cut the share of education expenditures in its total GDP output, and the share of this sector has been reduced from $2.6 \%$ in 2000 to $1.8 \%$ in the years 2002-2005. On the other hand, according to the UN Human Development Report, the share of different educational levels, (kindergarten and primary, high school and university) is different from the total expenditure of the education sector in the selected countries. 


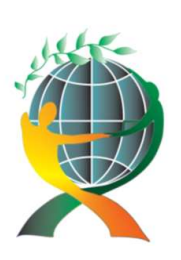

$$
\begin{gathered}
\text { (online) }=\text { ISSN } 2285-3642 \\
\text { ISSN-L }=2285-3642
\end{gathered}
$$

\section{Journal of Economic Development, Environment and People}

Volume 8, Issue 3, 2019

URL: http://jedep.spiruharet.ro

\begin{tabular}{|c|c|c|c|c|c|c|c|c|c|}
\hline \multirow{3}{*}{ Countries } & \multirow{3}{*}{$\begin{array}{c}\text { Human } \\
\text { Development } \\
\text { Rank }\end{array}$} & \multicolumn{2}{|c|}{ Education cost } & \multirow{2}{*}{\multicolumn{3}{|c|}{$\begin{array}{l}\text { Contribution the different levels } \\
\text { of education and the education } \\
\text { cost }\end{array}$}} & \multirow{3}{*}{$\begin{array}{l}\text { Women's } \\
\text { literacy } \\
\text { rate for } \\
\text { age over } \\
15 \text { years } \\
\text { old }\end{array}$} & \multirow{3}{*}{$\begin{array}{l}\text { Literacy } \\
\text { rates } \\
\text { compared } \\
\text { to men }\end{array}$} & \multirow{3}{*}{$\begin{array}{l}\text { The } \\
\text { proportior } \\
\text { of women } \\
\text { admitted } \\
\text { to } \\
\text { university }\end{array}$} \\
\hline & & \multirow{2}{*}{$\begin{array}{l}\text { As } \\
\text { part } \\
\text { of } \\
\text { GDP }\end{array}$} & \multirow{2}{*}{$\begin{array}{l}\text { As part of } \\
\text { government } \\
\text { payments }\end{array}$} & & & & & & \\
\hline & & & & $\begin{array}{l}\text { Kindergarten } \\
\text { \& primary } \\
\text { school }\end{array}$ & $\begin{array}{l}\text { High } \\
\text { school }\end{array}$ & University & & & \\
\hline Norway & 1 & 6.7 & 2.16 & 5.36 & 0.33 & 5.27 & - & - & 0.99 \\
\hline Japan & 11 & 6.3 & 5.10 & 2.38 & 8.39 & 9.14 & - & - & 0.47 \\
\hline Germany & 20 & 6.4 & 5.9 & 8.22 & 0.49 & 5.24 & - & - & 0.51 \\
\hline Argentina & 34 & 0.4 & 8.13 & 3.43 & 2.39 & 5.17 & 2.97 & 0.100 & 0.72 \\
\hline Malaysia & 61 & 1.8 & 3.20 & 0.32 & 5.33 & 3.33 & 4.85 & 0.93 & 0.33 \\
\hline $\begin{array}{l}\text { Saudi } \\
\text { Arabia }\end{array}$ & 77 & - & - & - & - & - & 3.69 & 0.80 & 0.30 \\
\hline Turkey & 94 & 7.3 & - & 7.37 & 1.30 & 2.32 & 1.81 & 0.85 & 0.24 \\
\hline Iran & 99 & 9.4 & 7.17 & 1.25 & 0.36 & 1.17 & 4.70 & 0.84 & 0.22 \\
\hline $\begin{array}{l}\text { South } \\
\text { Africa }\end{array}$ & 120 & 3.5 & 5.18 & 8.47 & 3.31 & 6.14 & 9.80 & 0.96 & 0.16 \\
\hline India & 127 & 1.4 & 7.12 & 4.38 & 1.40 & 3.20 & 8.47 & 0.65 & 0.10 \\
\hline Pakistan & 135 & 81. & 8.7 & - & - & - & 2.35 & 0.57 & 0.2 \\
\hline
\end{tabular}

e-mail: office jedep@spiruharet.ro

Source: UN human development report 2019

For example, from the years 2002 to 2005 , Norway has divided its education budget with ratio, $36.5 \%$, $33 \%$ and $27.5 \%$, into the difference grades of kindergarten and primary school, high school and the university is divided. However, in- country Iran, the share of academic grades is mentioned, from the budget of the education sector for each one is $25.1,36$ and $17.1 \%$. It seems to be in most countries the kindergarten and primary school section has a larger share of the education budget, which indicates the importance of the basic level of education. On the other hand, examines of the literacy rates for the women over age 15, as one of the indicators of the UN human development report, it shows that in 2007, about $70.4 \%$ of women over the age of 15 were literate in Iran. In compare to the proportion of over age 15 -year-old women in countries such as Pakistan with a rate of $35.2 \%$ and India with a share of $47.8 \%$, it seems a significant ratio. But, compared with Argentina, with ratio $97.2 \%$ for women with a literacy rate at age over 15 years, points to the need for more attention from the Iranian government and in Turkey, this rate is $81.1 \%$ for the women over age 15 years old (Sodagary, 2019). 


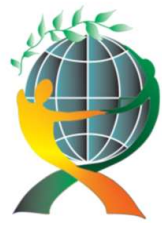

\author{
(online) $=$ ISSN $2285-3642$ \\ ISSN-L = $2285-3642$ \\ Journal of Economic Development, Environment and People \\ Volume 8, Issue 3, 2019 \\ URL: http://iedep.spiruharet.ro \\ e-mail: office jedep@spiruharet.ro
}

\title{
7. Describing Globalization Index Data
}

The description of the data related to the globalization index is extracted from the following resources: World Development Indicators; International Financial Statistic Yearbook; Telecommunications Union Yearbook of statistics; Compendium of Tourism statistics; Balance of Payment statistics; World Fact book.

The globalization index is not just economical and it is including political, technical, and individual factors but it does not include cultural criteria. Of course, for the coming years, with the efforts of two researchers at the University of Singapore, the culture has to be assessed for countries through imports and exports, and the press is also being evaluated. According to the Globalization Index, Europe is the most globalized region due to its free trade, foreign investment and easy condition of travel without a passport. (Glaister, 2013) According to experts from the Kearney International Counselling Institute, the most important indicator of globalization is a direct foreign investment because it is combined with economics, politics and technology.

\section{Globalization indicators are based on four factors:}

- Economic factors: international trade, direct foreign investment, investment in bonds and income from the investment area.

- Individual factors: Foreign calls traffic, Tourism, International money transfers.

- Technical factors: Internet users, Internet hosts, secure Internet servers.

- Political factors: membership in international organizations, participation in the United Nations and Security Council and increase of embassies and contracts.

\section{The Relations between Globalization Index and Human Development Index}

The relationship between the Globalization Index and the Human Development Index can be quantified quantitatively. According to data from the thirteenth globalization indexes and triple human development indicators that were published by the International Institute of Coronaries (Kearney) and the World Bank during 2019, also using the Spearman Correlation Coefficient The degree of correlation between the two indicators is calculated to be $\mathrm{R}=76 \%$, which indicates that there is a close correlation between the Globalization Index and the Human Development Index, as we can see in the figure 3.

The success of governments in terms of globalization indicators reflects the human development of those countries. In other words, countries with a high rank in terms of globalization index, as a consequence, are ranked first in terms of human development indicators. (Axel et al, 2019). 

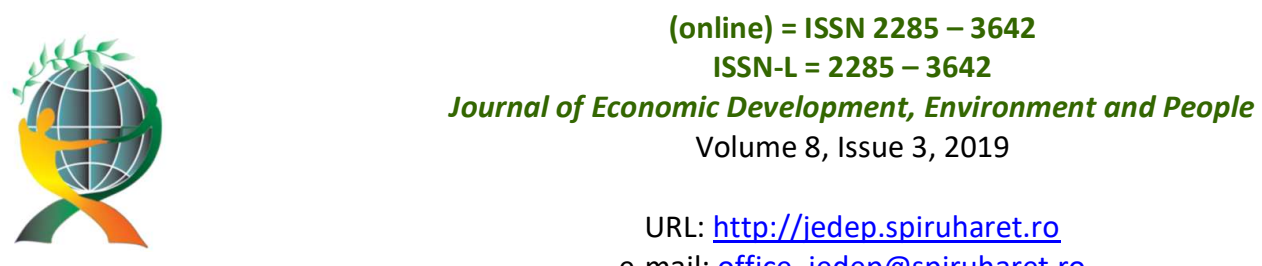

URL: http://jedep.spiruharet.ro

e-mail: office jedep@spiruharet.ro

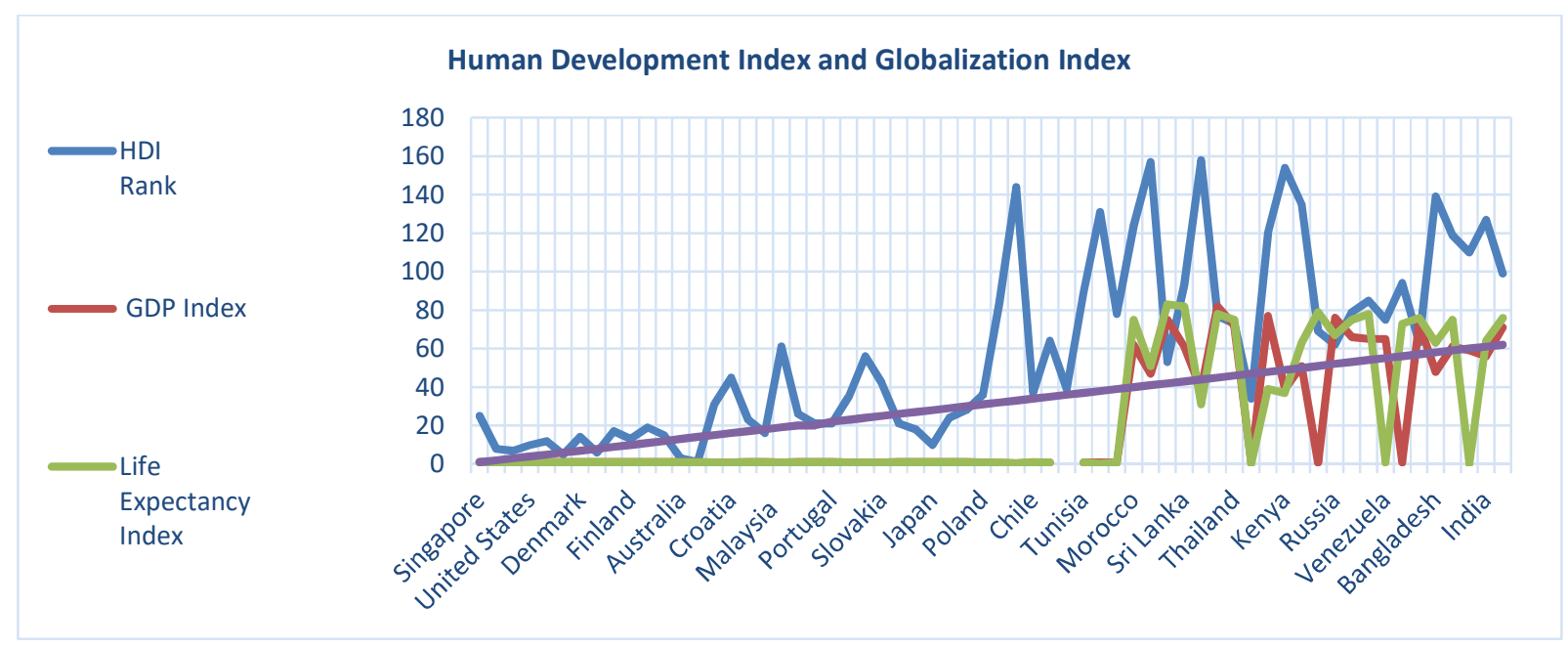

Figure 3. Human Development Index and Globalization Comparison

Source: Global Sustainable Development Report: Sustainable Development Knowledge Platform, 2019

* The Globalization Index has been ranked among 62 countries.

** The Human Development Index is ranked among 177 countries.

\section{Conclusion}

As described in the paper, globalization indicators are published annually by the International Institute of Kearney, which has four components: 1. Economic; 2. Political; 3. Technical; 4. Individual (Hallak, 1999). Each component has several indexes as follows:

-Economic component, Indicators: International trade and foreign investment.

-The political component has the following indicators: membership in international organizations, participation in the United Nations, Council of Europe, one-way and two-way contracts and the number of embassies.

-The technical component has indexes: Internet users, Internet hosts, and secure Internet servers.

-Individual components have indicators such as tourism, international money transfers and foreign exchange traffic. (Glaister, 2013)

The human development index has also three components: life expectancy, education and GDP. After extracting information about two indicators, and processing information, using STATGRAF statistical software, and then the correlation coefficient between two indices is calculated. The intensity of the correlation between of the two indexes is $R=0.76$, which indicates that there is a direct correlation between these two indices. So we can say the more countries succeed in the globalization process, the more successful they will be in the human development process.

Therefore, it is necessary for countries to develop a human index, Take action and work on the globalization index. 


\author{
(online) $=$ ISSN $2285-3642$ \\ ISSN-L = $2285-3642$ \\ Journal of Economic Development, Environment and People \\ Volume 8, Issue 3, 2019 \\ URL: http://jedep.spiruharet.ro \\ e-mail: office jedep@spiruharet.ro
}

\title{
9. References
}

[1]. Axel, D., Noel, G., Pim, M., and Lotte, V. (2019), Measuring globalization opening the black box. A critical analysis of globalization indices, https://cyberleninka.ru/article/n/measuring-globalization-opening-the-blackbox-a-critical-analysis-of-globalization-indices.

[2]. Analoui, F. (2000), Human resource management issues in developing countries, Aldershot: Ashgate.

[3]. Baklouti, N. and Boujelbene, Y., (2018), A simultaneous equation model of economic growth and shadow economy: Is there a difference between the developed and developing countries? Econ Change Restruct, pp:120,https://doi.org/10.1007/s10644-018-9235-8

[4]. Cinnirella, F. and Streband J., (2017), The role of human capital and innovation in economic development: evidence from post-Malthusian Prussia, Journal of Economic Growth, 22(2), pp: 193-227.

[5]. Della Posta, P., Uvalić, M., and Verdun, A. (2009), Globalization, development, and integration. Houndmills, Basingstoke, Hampshire [England]: Palgrave Macmillan.

[6]. Dwivedi, O. P., Khator, R., and Nef, J., (2007), Managing development in a global context, Basingstoke: Palgrave Macmillan.

[7]. Fernihough, A., (2017), Human capital and the quantity-quality trade-off during the demographic transition, Journal of Economic Growth, 22(1), pp:35-65, https://doi.org/10.1007/s10887-016-9138-3.

[8]. Glaister, A., (2013), HR outsourcing: the impact on HR role, competency development and relationships, Human Resource Management Journal, 24(2), pp: 211-226. doi: 10.1111/1748-8583.12031.

[9]. Global Internet usage, (2019), https://en.wikipedia.org/wiki/Global_Internet_usage.

[10]. FORUM-ASIA, (2000), International Conference on Corruption, Democracy, and Development Report, Bangkok, Thailand.

[11]. Hansen, Casper W. and Holger Strulik, (2017), Life expectancy and education: evidence from the cardiovascular revolution, Journal of Economic Growth, 2017, vol. 22, issue 4, pp: 421-450.

[12]. Human Development Index - Infogalactic: the planetary knowledge core, (2019), https://infogalactic.com/info/Human_Development_Index.

[13]. Huntington, S.P. and Harrison, L.E., (2000), Culture matters: How values shape human progress, New York: Basic Books.

[14]. Kornai, J., Mátyás, L., and Roland, G., (2009), Corruption, development and institutional design. Basingstoke: Palgrave Macmillan.

[15]. Laudicina, Paul A., Erik R. Peterson and Courtney Rickert McCaffrey, (2019), The 2019 A.T. Kearney Foreign Direct Investment Confidence Index ${ }^{\circledR}$ : Facing a Growing Paradox, , Global Business Policy Council, Research Report, https://www.atkearney.com/foreign-direct-investment-confidence-index.Todaro, M.P. and Smith, S.C., (2006), Economic development, Boston: Pearson Addison Wesley.

[16]. Lundby, K.M. and Jolton, J., (2010), Going global: Practical applications and recommendations for HR and OD professionals in the global workplace, San Francisco: Jossey-Bass.

[17]. Marquardt, M.J. and Engel, D.W., (1993), Global human resource development, Engelwood Cliffs, NJ: Prentice Hall.

[18]. Owens, E., (1987), The future of freedom in the developing world: Economic development as political reform, New York: Pergamon Press.

[19]. Payne, S. ,(2019), Gross Domestic Product, http://theinfolist.com/php/SummaryGet.php?FindGo=Gross\%20Domestic\%20Product

[20]. Pinkovskiy, Maxim L.,(2017), Growth discontinuities at borders, Journal of Economic Growth, vol. 22, issue 2, pp: 145192, https://econpapers.repec.org/article/kapjecgro/v 3a22 3ay 3a2017 3ai 3a2 3ad 3a10.1007 5fs10887-0169139-2.htm.

[21]. Silbereisen, R., and Chen, X., (2010), Social change and human development, Los Angeles: SAGE. 


\section{(online) = ISSN $2285-3642$ \\ ISSN-L = 2285 - 3642}

Journal of Economic Development, Environment and People

Volume 8, Issue 3, 2019

URL: http://jedep.spiruharet.ro

e-mail: office jedep@spiruharet.ro

[22]. Sodagary, M., (2019), How to invest in Iran, http://www.howtoinvestiniran.com/review-of-latest-humandevelopment-indexs-report-hdi-for-iran.

[23]. UN Sustainable Development Knowledge Platform, (2019), Global Sustainable Development Report: https://sustainabledevelopment.un.org/globalsdreport.

[24]. United Nations Development Programme (2019), Human Development Reports, http://hdr.undp.org/

[25]. Vujakovic, P., (2010), How to Measure Globalization? A New Globalization Index (NGI), Atlantic Economic Journal, 38(2), pp: 237-237, doi: 10.1007/s11293-010-9217-3.

[26]. Watts, T., (2011), A collective approach to skills development, Strategic HR Review, 10(1), doi: 10.1108/shr.2011.37210aae.001.

Annex 1: Human Development Index and Globalization

\begin{tabular}{|c|c|c|c|c|c|}
\hline Countries & $\begin{array}{c}\text { Globalisation } \\
\text { Rank }\end{array}$ & HDI Rank & $\begin{array}{c}\text { GDP } \\
\text { Index }\end{array}$ & $\begin{array}{l}\text { Life } \\
\text { Expectancy } \\
\text { Index }\end{array}$ & $\begin{array}{c}\text { GDP per Capital } \\
\text { Annual Growth } \\
\text { Rate }\end{array}$ \\
\hline Singapore & 1 & 25 & 0.92 & 0.89 & $4.5 \quad 4.9$ \\
\hline Ireland & 2 & 8 & 0.99 & 0.88 & 4.56 .7 \\
\hline Swiss & 3 & 7 & 0.96 & 0.93 & 1.00 .5 \\
\hline United States & 4 & 10 & 0.99 & 0.87 & $2.0 \quad 2.1$ \\
\hline Netherlands & 5 & 12 & 0.95 & 0.89 & $1.8 \quad 2.1$ \\
\hline Canada & 6 & 5 & 0.96 & 0.92 & $1.6 \quad 2.3$ \\
\hline Denmark & 7 & 14 & 0.96 & 0.87 & $\begin{array}{ll}1.6 & 1.9\end{array}$ \\
\hline Sweden & 8 & 6 & 0.93 & 0.92 & $2.0 \quad 1.6$ \\
\hline Austria & 9 & 17 & 0.95 & 0.90 & $\begin{array}{ll}1.8 & 2.1 \\
\end{array}$ \\
\hline Finland & 10 & 13 & 0.94 & 0.89 & 2.52 .0 \\
\hline New Zealand & 11 & 19 & 0.90 & 0.90 & 2.11 .0 \\
\hline England & 12 & 15 & 0.94 & 0.89 & $2.5 \quad 2.1$ \\
\hline Australia & 13 & 3 & 0.95 & 0.92 & $2.6 \quad 1.9$ \\
\hline Norway & 14 & 1 & 0.99 & 0.91 & 2.92 .8 \\
\hline Czech Republic & 15 & 31 & 0.85 & 0.81 & $1.5 \quad \ldots$. \\
\hline Croatia & 16 & 45 & 0.79 & 0.83 & $2.1 \quad \ldots$. \\
\hline Palestine & 17 & 23 & 0.88 & 0.91 & $1.6 \quad 1.9$ \\
\hline France & 18 & 16 & 0.94 & 0.91 & $\begin{array}{ll}1.6 & 1.7 \\
\end{array}$ \\
\hline Malaysia & 19 & 61 & 0.76 & 0.80 & $3.4 \quad 3.9$ \\
\hline Slovenia & 20 & 26 & 0.88 & 0.86 & $3.1 \quad \ldots$. \\
\hline Germany & 20 & 21 & 0.94 & 0.90 & $1.3 \quad 2.0$ \\
\hline Portugal & 22 & 21 & 0.87 & 0.87 & $2.2 \quad 2.7$ \\
\hline Hungary & 23 & 35 & 0.83 & 0.80 & $\begin{array}{ll}2.6 & 1.1 \\
\end{array}$ \\
\hline Panama & 24 & 56 & 0.71 & 0.83 & 2.41 .0 \\
\hline Slovakia & 25 & 42 & 0.82 & 0.82 & 2.40 .51 \\
\hline Spain & 26 & 21 & 0.90 & 0.92 & $2.4 \quad 2.2$ \\
\hline Italy & 27 & 18 & 0.94 & 0.92 & $1.5 \quad 2.0$ \\
\hline Japan & 28 & 10 & 0.94 & 0.95 & 1.02 .4 \\
\hline Greece & 29 & 24 & 0.88 & 0.89 & 2.11 .0 \\
\hline South Korea & 30 & 28 & 0.87 & 0.87 & $4.6 \quad 6.1$ \\
\hline
\end{tabular}




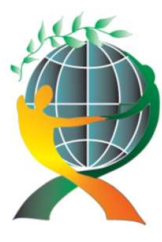

\author{
(online) $=$ ISSN $2285-3642$ \\ ISSN-L = 2285 - 3642 \\ Journal of Economic Development, Environment and People \\ Volume 8, Issue 3, 2019
}

URL: http://jedep.spiruharet.ro

e-mail: office jedep@spiruharet.ro

\begin{tabular}{|c|c|c|c|c|c|}
\hline Poland & 31 & 36 & 0.79 & 0.81 & $4.2 \ldots$ \\
\hline Philippines & 32 & 84 & 0.63 & 0.76 & $\begin{array}{ll}1.2 & 0.3\end{array}$ \\
\hline Uganda & 33 & 144 & 0.45 & 0.37 & 3.92 .61 \\
\hline Chile & 34 & 37 & 0.77 & 0.88 & 4.14 .0 \\
\hline Romania & 35 & 64 & 0.72 & 0.77 & 0.60 .81 \\
\hline Taiwan & 36 & 39 & & & \\
\hline Tunisia & 37 & 89 & 0.71 & 0.80 & $\begin{array}{ll}3.1 \quad 2.1 \\
\end{array}$ \\
\hline Batswana & 38 & 131 & 0.75 & 0.19 & $2.7 \quad 5.1$ \\
\hline Ukraine & 39 & 78 & 0.67 & 0.69 & $-4.7-5.7$ \\
\hline Morocco & 40 & 124 & 0.62 & 0.75 & 1.01 .3 \\
\hline Senegal & 41 & 157 & 0.47 & 0.51 & 1.30 \\
\hline Mexico & 42 & 53 & 0.75 & 0.83 & $\begin{array}{ll}1.4 & 0.9 \\
\end{array}$ \\
\hline Sri Lanka & 43 & 93 & 0.61 & 0.82 & $3.3 \quad 3.4$ \\
\hline Nigeria & 44 & 158 & 0.39 & 0.31 & $\begin{array}{ll}0 & -0.5 \\
\end{array}$ \\
\hline Saudi Arabia & 45 & 77 & 0.82 & 0.78 & $-0.6-2.4$ \\
\hline Thailand & 46 & 73 & 0.72 & 0.75 & 2.81 .5 \\
\hline Argentina & 47 & 34 & 0.80 & $0 / 82$ & 1.30 .4 \\
\hline South Africa & 48 & 120 & 0.77 & 0.39 & $0.1-0.6$ \\
\hline Kenya & 49 & 154 & 0.39 & 0.37 & $\begin{array}{lll}-0.6 & 0.2 \\
\end{array}$ \\
\hline Pakistan & 50 & 135 & 0.51 & 0.63 & $1.1 \quad 2.5$ \\
\hline Columbia & 51 & 69 & 0.70 & 0.79 & $0.4 \quad 1.4$ \\
\hline Russia & 52 & 62 & 0.76 & 0.67 & $-1.5-2.1$ \\
\hline Peru & 53 & 79 & 0.66 & 0.75 & $2.1-1.5$ \\
\hline China & 54 & 85 & 0.65 & 0.78 & 5.82 .8 \\
\hline Venezuela & 55 & 75 & 0.65 & 0.80 & $-1.5-1.1$ \\
\hline Turkey & 56 & 94 & 0.70 & 0.73 & 1.31 .8 \\
\hline Brazil & 57 & 63 & 0.73 & 0.76 & 1.20 .8 \\
\hline Bangladesh & 58 & 139 & 0.48 & 0.63 & 1.31 .9 \\
\hline Egypt & 59 & 119 & 0.61 & 0.75 & 2.52 .7 \\
\hline Indonesia & 60 & 110 & 0.59 & -- & 2.01 .4 \\
\hline India & 61 & 127 & 0.56 & 0.64 & 0.43 .3 \\
\hline Iran & 62 & 99 & 0.71 & 0.76 & $1.2-0.3$ \\
\hline
\end{tabular}

Source: www.Human Kearney.com 